\title{
Conceptual matrix for the biofuels of the future applicable to the Romanian economy
}

\author{
Gheorghe Lăzăroiu ${ }^{1, *}$, Lucian Mihăescu ${ }^{2}$, Gabriel Negreanu ${ }^{2}$, Viorel Berbece ${ }^{2}$, Elena- \\ Adriana Jarcu ${ }^{3}$, Laura Alexandra Stănescu ${ }^{3}$ \\ ${ }^{1}$ University Politehnica of Bucharest, Departament of Energy Production and Use, Adress: Splaiul \\ Independenţei, no 313, sector 6, Romania \\ ${ }^{2}$ University Politehnica of Bucharest, Departament Termotechnics, Engines, Thermal and Frigorific \\ Equipment, Adress: Splaiul Independenţei, no 313, sector 6, Romania \\ ${ }^{3}$ University Politehnica of Bucharest, Department of Hydraulics, Hydraulic Machinery and \\ Environmental Engineering, Adress: Splaiul Independenţei, no 313, sector 6, Romania
}

\begin{abstract}
Romania is in a full process of development in regards to producing energy from renewable sources. Successes have been recorded in the wind and hydro sectors, however, challenges are still to be solved in the field of biofuels. In previous years, research and investments targeting facilities that make use of a larger range of renewable fuels and their respective incineration technologies were carried out. The experience thus gained allows for a redefinition of the range of fuels which can constitute cost-worthy power producing solutions. Defining the renewable fuels of the future is of utmost importance for a country with a significant agricultural potential, but also with a temperate climate. After eliminating some cultures specific to warmer climates and not taking into account the quantity/price ratio, the current paper highlights a synthetic approach (a matrix) to the fuels of the future applicable to the power sector in Romania. At the definition base for the matrix also stands data gained from the experience of the researchers in the respective domain.
\end{abstract}

\section{Classification criteria of biofuels}

The notion of conceptual matrix for biofuels comes as a necessity in the definition and classification of a significant number of such fuels. Grouping these fuels from the perspective of provenience characteristics and technological applicability for energy production was considered.

The economic criteria will have a primordial position in the following grouping, the climate being, from this standpoint, an essential selection element [1],[2].

At the current technological development level there is a multitude of biofuel categories. The products resulted from their physico-chemical processing are more feasible to be used in producing energy. There are cases where biofuels in a natural (pure) state can be used alongside their by-products, a representative case being wood [3],[4].

* Corresponding author: glazaroiu@,yahoo.com 
In order for a biofuel to be used it has to fulfil the following conditions [4]:

- an initial plant production for a certain level of use;

- possibility to collect and store efficiently;

- the existence of an economic processing branch;

- efficient final use.

The biofuels of the future will be those that in time will amass all these four criteria. The evolution of society, which includes agriculture, technological development but also the increased power requirement and environmental protection, may contribute to the addition or subtraction of some biofuel categories from those targeted by the future [7]. The ratio between calorific power and fuel unit represents a prime economic criteria. The ratio between pollution (polluting emissions) generated and fuel unit represents the second socio-economic criteria.

The evolution in time, which essentially contributes to the definition of a future biofuel, indicates the following trends (Figure 1):

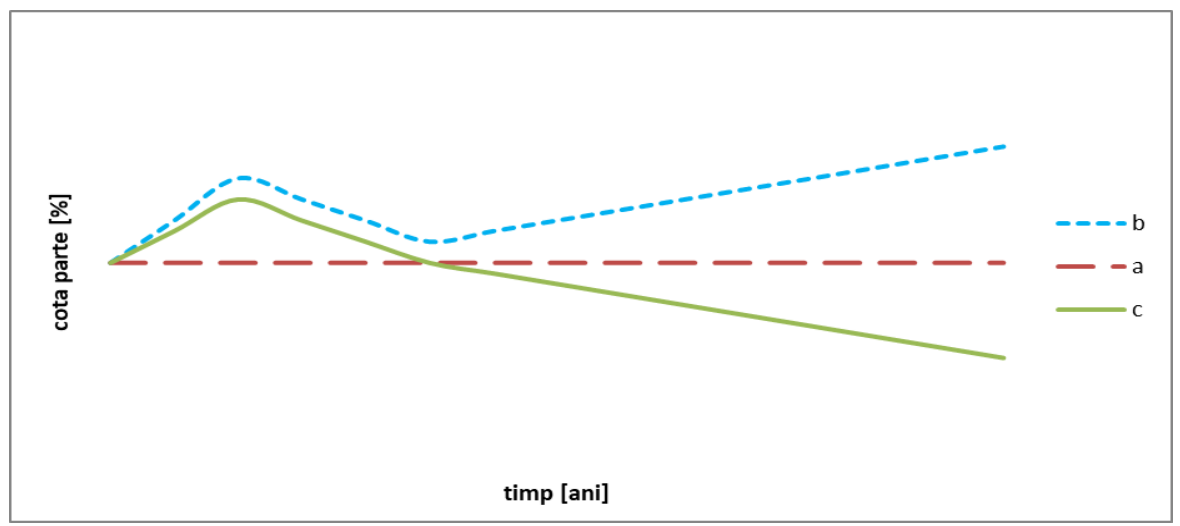

Fig 1. Evolution in time of biofuel consumption

The biofuels from the $a$ and $b$ categories will be considered the fuels of the future, as they exhibit a constant or increasing trend. Those from category $c$ do not present future interest.

The initial increase characterises the start of use for a specific biofuel and is due to the technological momentum, but is corrected in time by real working conditions and costs.

The use of an alcohol fuel is highly desired due to the low or non-existent $\mathrm{CO}_{2}$ emissions. This leads to the initial definition of fuel production potential, starting from biomass production.

Alcohol production essentially targets two products:

- ethanol $\left(\mathrm{C}_{2} \mathrm{H}_{5} \mathrm{OH}\right)$, with hydrolysis and fermentation as the main processes, including almost all agricultural products and by-products;

- methanol $\left(\mathrm{CH}_{3} \mathrm{OH}\right)$, obtained through various physico-chemical processes, such as pyrolysis, gasification and chemical or biological synthesis, through methanogenic anaerobic fermentation.

Gasification leads to the formation of gaseous components represented by $\mathrm{CH}_{4}, \mathrm{CO}$, $\mathrm{CO}_{2}, \mathrm{H}_{2}$ and others, while anaerobic methanogenic fermentation leads to mainly $\mathrm{CO}_{2}$ and $\mathrm{CH}_{4}$.

Methanol can lead to easily obtained hydrogen, differing from the classic production branches based on methane and water dissociation. Methanol is also a synthesis source for ethylene.

In electrical energy production, methanol was imposed from an economic standpoint. 
For transportation, alongside methanol, ethanol was also adopted, usually mixed with classic hydrocarbons from petroleum. Research has proved that the percentages of $15 \%$ methanol and $20 \%$ ethanol cannot be surpassed.

Oil type biomass leads to the formation of metal-esters (biodiesel) through chemical treatment with alcohol.

The state of aggregation (solid, liquid or gaseous) will represent an essential group in the fuel matrix, more so since some of the fuels change states through physico-chemical processing. Technologically, liquid and gaseous fuels present advantages in respect to storage and combustion, and if the price rises compared to the base starting fuel, it will have to be analysed against the price of fossil fuels.

An essential economy cycle includes the comparison between energy price and total production costs.

\section{Primary and secondary usable biomass in Romania}

According to HG 1844/2005 [5], biomass represents the biodegradable part of products, waste and agricultural waste (including related animal and industrial), forestry and its connected industries, as well as the biodegradable components of industrial and urban waste.

Alongside primary biomass, directly resulted from photosynthesis, secondary biomass has, in time, gained an increasing margin, due to the technological developments and environmental protection standards [6].

The residues can be classified as primary, secondary and tertiary residues.

The primary residues are products represented by plants or forestry elements. From the activity to which this class of residues is subjected to in order to obtain dietary products, the secondary class of residue is obtained.

Energy crops are steered towards starch, sugar or oil producing plants, or lignocellulosic crops [8].

From the perspective of energy producing biomass it should be mentioned that Romania, due to its significant agricultural potential and continentally temperate climate, is a large cereal and oil producer, the rest of the energy crops, including willow, being in the definition phase.

For Romania, through the Strategy for use of renewable resources, according to HG $1535-2003$ [9], the share of biofuels will have to reach the value of $6.87 \%$ of power production by the year 2020 .

Concerning the biofuels that can be obtained from the agricultural sector the following data regarding potential can be mentioned [8][10]:

- for cereal crops, the production of straw used in energy generation is $2 * 10^{6} \mathrm{t} / \mathrm{ha}$ leading to $7 * 10^{6} \mathrm{t}$ /year being produced, which translates to $7.5^{*} 10^{5}$ toe/year;

- from a surface of about 2.5-2.7 million ha cultivated with corn, a quantity of stems of up to $17 \mathrm{mil}$. t/year and $2 \mathrm{mil}$. t/year of cobs can be produced. From an energy production perspective, around $60 \%$ of the total quantity can be used;

- from a surface of about 1 million ha cultivated with sunflower, around 1.8 mil. $\mathrm{t} /$ year of stems can be obtained. The shells, with a high calorific power, are also used for the purpose of energy production;

- grape plant vines resulting from maintenance operations carried out in viticulture amount to around $2.2 * 10^{5} \mathrm{t} /$ year, and about $2.3 * 10^{5} \mathrm{t}$ /year of biomass can be obtained from orchard maintenance.

It should be mentioned that in 2018, Romania was determined to be the largest producer of corn and sunflower in Europe. 
Rapeseed is cultivated on around 0.75 mil. ha, the oil being almost exclusively dedicated to the transportation sector. It is worth acknowledging that in the past few years, the stems of the plants have also started being used for energy production.

The forest sourced biomass potential is also significant in Romania, an important percentage of the produced wood being directed towards direct combustion in the citizen's homes (around $65 \%$ of Romanians use fire for heating) but also towards power production.

In Figure 2, the evolution of wood type biomass harvesting for Romania can be observed, including the harvesting for direct burning.

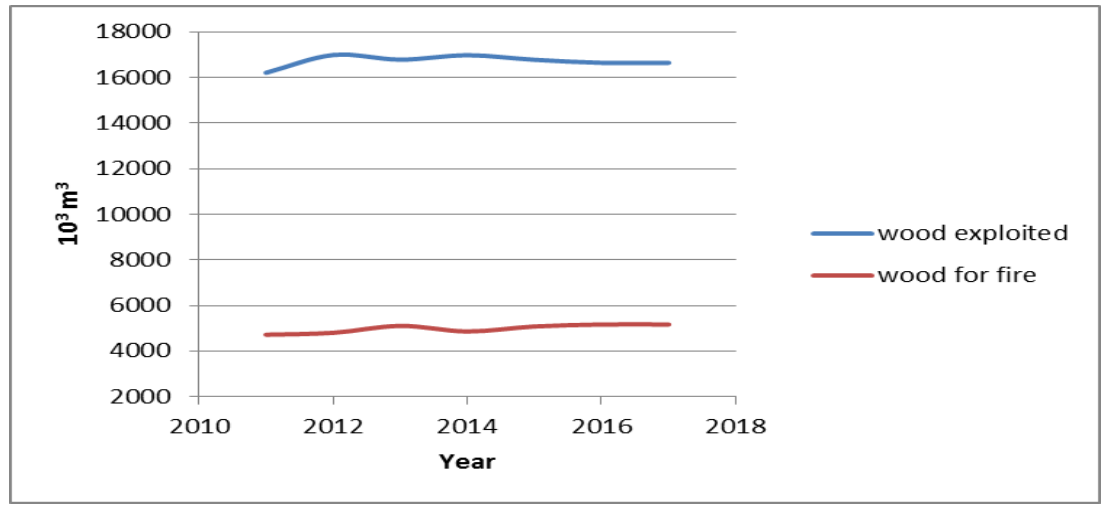

Fig 2. The evolution in time of wood production in Romania [10]

Although wood represents the oldest biofuel used, the requirement to limit its humidity before combustion will always remain a drawback. The simplest prerequisite limits the humidity to $30 \%$, but as the demands of the various combustion technologies develop, this limit gains multiple nuances.

These humidity related aspects reflect also on the willow used for energy production purposes, relatively underdeveloped in Romania (around 2500 ha). Although the combustion technology for this type of willow has developed accordingly, being considered an agricultural crop it has to adhere to inhibiting regulations.

The criteria of calorific power is outlined as can be observed from the data in Table 1 by all the biofuels, representing the limitations provided by the humidity content (wood is especially affected). For reference, it should be mentioned that the calorific power of lignite variates between $9000-9500 \mathrm{~kJ} / \mathrm{kg}$.

Table 1. The calorific power of some biofuels, in $\mathrm{kJ} / \mathrm{kg}$

\begin{tabular}{|l|l|l|l|}
\hline \multicolumn{1}{|c|}{ Biofuel } & \multicolumn{1}{|c|}{$\begin{array}{c}\text { The calorific power in } \\
\text { anhydrous state }\end{array}$} & \multicolumn{1}{c|}{ Biofuel } & \multicolumn{1}{c|}{$\begin{array}{c}\text { The calorific power in } \\
\text { anhydrous state }\end{array}$} \\
\hline $\begin{array}{l}\text { Sunflower seed } \\
\text { shells }\end{array}$ & 16200 & Corn cobs & $17200-17600$ \\
\hline Sunflower stems & $21000-21800$ & Wine plant vines & 16500 (humidity 7\%) \\
\hline Wheat straw & $17000-18500$ & $\begin{array}{l}\text { Fruit tree vines and } \\
\text { branches }\end{array}$ & 15000 (humidity 7\%) \\
\hline Barley straw & $15000-15500$ & Wood & 15500 \\
\hline Corn stems & $15500-16200$ & $\begin{array}{l}\text { Willow for energy } \\
\text { use }\end{array}$ & 15000 \\
\hline
\end{tabular}

The influence of humidity on the calorific power of wood and willow is given by the graph in Figure 3. 


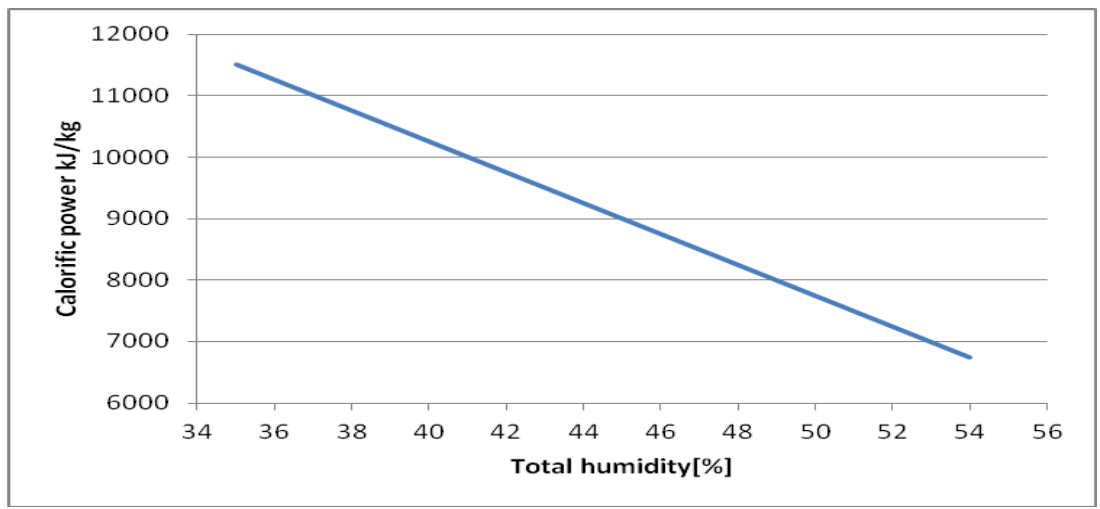

Fig 3. The importance of the relationship between total humidity and calorific power [10]

Starting from these aspects, the primary biomass nomenclature for the Romanian environment is presented in Table 2, from a current potential of use perspective.

Table 2. Future biofuels in Romania

\begin{tabular}{|c|c|c|c|c|c|}
\hline \multirow[t]{3}{*}{ Feedstock } & \multicolumn{5}{|c|}{ Biofuels } \\
\hline & \multirow[b]{2}{*}{ 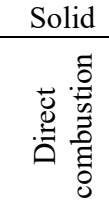 } & \multicolumn{3}{|c|}{ Liquid } & \multirow[b]{2}{*}{$\begin{array}{c}\text { Gaseous } \\
\text { 品 } \\
.0 \\
\infty\end{array}$} \\
\hline & & 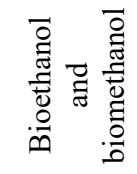 & $\begin{array}{l}\overline{0} \\
.0 \\
: 0 \\
.0 \\
00\end{array}$ & 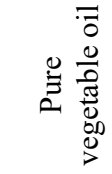 & \\
\hline A - Forest biomass & & & & & \\
\hline $\begin{array}{l}\text { A1 }- \text { Raw } \text { wood } \\
\text { (firewood) }\end{array}$ & A1.1 & & & & \\
\hline $\begin{array}{l}\text { A2 - Industrial wood } \\
\text { waste }\end{array}$ & A 2.1 & & & & \\
\hline $\begin{array}{l}\text { A3 - Pellets and } \\
\text { briquettes }\end{array}$ & A3.1 & & & & \\
\hline $\begin{array}{l}\text { A4 - Char, pyrolysis } \\
\text { gas }\end{array}$ & A 4.1 & A 4.3 & & & \\
\hline $\begin{array}{l}\mathrm{B}-\text { Agricultural } \\
\text { products }\end{array}$ & & & & & \\
\hline $\begin{array}{l}\text { B1 - Cereals (barley, } \\
\text { oats, rye, wheat) }\end{array}$ & & B1.3 & B1.2 & & \\
\hline B2 - Sugarcane & & B2.3 & & & B2.3 \\
\hline B3 - Sorghum & $\begin{array}{l}\text { Stems } \\
\text { B3.1 }\end{array}$ & & B3.3 & B3.3 & B3.3 \\
\hline B4 - Rapeseed & & B4.3 & B4.2 & B4.2 & \\
\hline
\end{tabular}




\begin{tabular}{|c|c|c|c|c|c|}
\hline $\begin{array}{l}\text { B5 - Corn kernels, } \\
\text { stalks, cobs }\end{array}$ & B5.1 & B5.3 & & B5.2 & B5.3 \\
\hline $\begin{array}{l}\text { B6 - } \\
\text { (stems, shells, seeds) }\end{array}$ & B6.1 & B6.3 & B6.3 & B6.1 & \\
\hline B7 - Potato & & B7.3 & & & \\
\hline B8 - Soy & & & B8.2 & B8.1 & \\
\hline $\begin{array}{l}\text { B9 - Cereal straw } \\
\text { (ballots, briquettes, } \\
\text { pellets) }\end{array}$ & B9.1 & & B9.3 & & B9.3 \\
\hline $\begin{array}{l}\text { B10- Willow and } \\
\text { poplar for power } \\
\text { production (chips, } \\
\text { briquettes, pellets) }\end{array}$ & B10.1 & & & & \\
\hline $\begin{array}{l}\mathrm{C}- \\
\text { sources }\end{array}$ & & & & & \\
\hline $\begin{array}{l}\mathrm{C} 1 \\
\text { (cords) }\end{array}$ & $\mathrm{C} 1$ & & & & \\
\hline D - Tree farm sources & & & & & \\
\hline $\begin{array}{ll}\mathrm{D} 1-\text { fruit } & \text { trees, } \\
\text { ornamental } & \text { trees, } \\
\text { leaves, branches }\end{array}$ & D1 & & & & \\
\hline $\mathrm{E}$ - Animal fats & E1 & & & & \\
\hline $\mathrm{F}$ - Animal protein & & & & & F3 \\
\hline $\begin{array}{l}\mathrm{G}-\text { Combustible } \\
\text { municipal waste }\end{array}$ & G1 & & & & G3 \\
\hline $\begin{array}{ll}\mathrm{H}-\text { Organic } & \text { and } \\
\text { combustible } & \\
\text { industrial waste } & \\
\end{array}$ & H1 & & & & H3 \\
\hline I - Water treatment & & & & & $\mathrm{I} 3$ \\
\hline $\mathrm{J}$ - Waste & $\mathrm{J} 1$ & & & & $\mathrm{~J} 3$ \\
\hline
\end{tabular}

Reducing the impact on the environment was also taken into account. The development of pellet production has recently lead to the use of a large range of shells, seeds and roots in products to be used in energy production [12], [14], [15].

The matrix has on the abscissa the provenience of the biofuels, and on the ordinate the state in which the fuel is used (Figure 4). 
A1

A1.1 A2.1 A3.1 A4.1

A6.2

A5.3
$\begin{array}{lllllllll}B 1 & B 2 & B 3 & B 4 & B 5 & B 7 & B 8 & B 9 & B 10\end{array}$

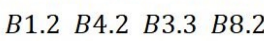

$\begin{array}{llll}B 1.3 & B 2.3 \quad B 3.3 \quad B 4.3 \quad B 6.3 \quad B 7.3 \quad B 9.3\end{array}$

$$
\begin{array}{cccccccc}
C & D & E & F & G & H & I & J \\
C 1 & D 1 & E 1 & & G 1 & H 1 & & J 1 \\
& & & F 3 & G 3 & H 3 & I 3 & J 3
\end{array} \mid
$$

Fig 4. The matrix of future biofuels in Romania

From the biofuel matrix some fuels were removed, considered to not be economically feasible for Romania, the majority of which being unfit for the climate, amongst which:

- sugarcane

- artichoke (Cynara)

- elephant grass (Miscanthus)

- palm, coconut tree and macadamia

- panicum virgatum

- phalaris Arundinacea

- eucalyptus

- paulownia

- hemp

- cameline

\section{Biofuel usage scale in Romania for energy production}

In Romania, during year 2018, the installed power in electrical energy producing facilities from biofuels was $124.16 \mathrm{MW}$, in 28 units, according to data from ANRE [13].

Depending on the biofuel used and synthesised in the matrix presented before, the electrical energy producing units (some with cogeneration) can be grouped as following in the Table 3:

\begin{tabular}{|c|c|c|}
\hline Biofuel & Company & Installed electrical power, MW \\
\hline A1 & A6 IMPEX S.R.L. - Dej & 9.73 \\
\hline \multirow{9}{*}{ A2 } & $\begin{array}{llll}\text { EGGER } & \text { ROMANIA } & \text { S.R.L. } \\
\text { Rădăuți } & & \end{array}$ & 14.5 \\
\hline & SAUCOLEMN S.R.L. & 0.31 \\
\hline & FIRST BIOGAZ S.R.L. & 1.49 \\
\hline & $\begin{array}{l}\text { GENERAL ENERGETIC S.R.L. } \\
\text { - Pângărați }\end{array}$ & 6.5 \\
\hline & SORTILEMN S.A. - Gherla & 1.44 \\
\hline & $\begin{array}{l}\text { HOLZINDUSTRIE } \\
\text { SCHWEIGHOFER S.R.L. }\end{array}$ & 21.25 \\
\hline & $\begin{array}{lll}\text { EXPLOCOM GK } & \text { S.R.L. } & - \\
\text { Lupeni - Harghita } & & \end{array}$ & 0.82 \\
\hline & $\begin{array}{l}\text { BIO } \\
\text { TRANSILVANIA S.R.L. }\end{array}$ & 19.93 \\
\hline & BIOENERGY SUCEAVA S.R.L. & 29.65 \\
\hline \multirow{5}{*}{$\begin{array}{l}\text { B1.2, B1.3 } \\
\text { A4.3 } \\
\text { B5.3 } \\
\text { B6.3 }\end{array}$} & AAYLEX PROD S.R.L. & 2.26 \\
\hline & AGROTRUST S.R.L. & 0.25 \\
\hline & $\begin{array}{l}\text { ARMAN CONSTRUCTION } \\
\text { S.R.L. }\end{array}$ & 0.40 \\
\hline & COM ABM S.R.L. & 0.99 \\
\hline & $\begin{array}{ll}\text { IRIDEX } & \text { GROUP } \\
\end{array}$ & 3.60 \\
\hline
\end{tabular}

Table 3. Biofuels used in electrical energy production 


\begin{tabular}{|l|l|l|}
\hline \multirow{5}{*}{} & EXPORT S.R.L. & \\
\cline { 2 - 3 } & MEVCER S.R.L. & 0.50 \\
\cline { 2 - 3 } & NEW LIFE ENERGY S.R.L. & 0.50 \\
\cline { 2 - 3 } & RENEWABLE POWER S.R.L & 0.66 \\
\cline { 2 - 3 } & SANA RA S.R.L. & 1.60 \\
\cline { 2 - 3 } & TEB PROJECT ONE S.R.L. & 2.98 \\
\cline { 2 - 3 } & UAT ORASUL SEINI & 0.37 \\
\cline { 2 - 3 } & BIOCARNIC ESCO S.R.L. & 0.52 \\
\cline { 2 - 3 } & GENESIS BIOTECH S.R.L. & 1.06 \\
\hline \multirow{5}{*}{ B10.1 } & APASERV SATU MARE S.R.L. & 0.35 \\
\cline { 2 - 3 } & $\begin{array}{l}\text { COMPANIA DE APA ORADEA } \\
\text { S.A. }\end{array}$ & 0.72 \\
\cline { 2 - 3 } & $\begin{array}{l}\text { COMPANIA DE UTILITATI } \\
\text { PUBLICE S.A. }\end{array}$ & 0.25 \\
\hline & $\begin{array}{l}\text { BEST TEAM CONSULTING } \\
\text { S.R.L. }\end{array}$ & 0.25 \\
\cline { 2 - 3 } & RIG BIOMASS S.R.L. & 1.28 \\
\hline
\end{tabular}

The presented data shows that the dominant biofuel is wood stock $(85 \%)$, followed by biogas resulting from waste fermentation $(12.7 \%)$. This repartition of biofuel use leads to the conclusion that agricultural biomass is almost fully reused in electrical energy production [11].

The quantity of forestry biomass used in energy production is a consequence of the large exploited volumes. As can be seen in Figure 2 the quantity of wood used for fire has to be taken into account in the thermal energy scale of the country. To this, the agricultural biofuels, including the power production used willow, will be added.

If an average annual quantity of 3.5 million tons of firewood is to be considered for thermal energy production, for a thermal power of $3.3 \mathrm{kWh} / \mathrm{kg}$, the resulting produced thermal energy is $11.5^{*} 10^{6} \mathrm{MWh} / \mathrm{an}$. For an efficiency of $70 \%$, the actual thermal energy produced is around $8.08 * 10^{6} \mathrm{MWh} / \mathrm{an}$.

Referring to the biofuels of agricultural provenience, the use of cereal straw, corn stems, sunflower and cobs, represents the largest potential of use, although in power production under $10 \%$.

\section{Conclusions}

For energy production, both electrical and thermal, in Romania, in the biofuel balance the forestry sector has the largest margin. To be noted is the significant potential of agricultural biofuels.

Referring to the waste use, the range of applicability is extremely reduced, more so today, when the notion of circular economy is in full progress.

From the census of biofuel use in electrical and thermal energy production, an extremely reduced number of biofuels that are actually used can be observed.

\section{References}

1. G. Lazaroiu, L. Mihaescu, G. Negreanu, C. Pana, I. Pisa, A. Cernat, D-A. Ciupageanu, Experimental Investigations of Innovative Biomass Energy Harnessing Solutions, Energies, ISSN: 1996-1073, Volume 11 Issue:12, (2018) 
2. M. Balat and G. Ayar Biomass Energy in the World, Use of Biomass and Potential Trends, Journal Energy Sources, Volume 27 Issue 10, Pages. 931-940, (2006)

3. I. Pisa, G. Lazaroiu, C. Radulescu, L. Mihaescu, Experimental Studies on the Corrosion Occurrence During Biomass Combustion Process, Environmental Engineering and Management Journal, ISSN: 1582-9596, EISSN: 1843-3707, Volume: 11, Issue: 9, Pages: 1555-1560, (2012)

4. G. Lazaroiu, I. Oprea, L. Mihaescu, T. Prisecaru, I. Pisa, G. Negreanu, C.R. Mocanu, Biomass Briquettes from Pitcoal-Wood: Boiler Test Facility Combustion Case Study, Journal of Environmental Protection and Ecology, ISSN: 1311-5065, Volume: 13, Issue: 2a, Pages: 1070-1081, (2012)

5. Hotărârea nr. 1844/2005 privind promovarea utilizării biocarburanților și a altor carburanți regenerabili pentru transport

6. T. Vintila, S. Neo, Biogas in Romanian Agriculture, Present and Perspectives, Scientific Papers: Animal Science and Biotechnologies 44, (2011)

7. Directive 2003/30/Ec of the European Parliament and of the Council of 8 May 2003 on the Promotion of the Use of Biofuels or Other Renewable Fuels for Transport, Official Journal of the European Union 17.5., L 123/42, (2003)

8. Run-Cang Sun, Cereal Straw as a Resource for Sustainable Biomaterials and Biofuels, Elsevier, ISBN: 978-0-444-53234-3

9. Hotărârea nr. $1535 / 2003$ privind aprobarea Strategiei de valorificare a surselor regenerabile de energie

10. G. Lazaroiu, L. Mihaescu, T. Vatuiu, I. Pasa, D-A. Bondrea, G.P. Negreanu, E-A. Jarcu, V. Berbece, Biomasa Solida Sursa de Energie Curata, Volume 2, (2018)

11. Study of Detection of Business Opportunities for Entrepreneurs and SMEs in Biomass Sector, $\quad$ https://ec.europa.eu/energy/intelligent/projects/sites/ieeprojects/files/projects/documents/biobusiness market opportunities.pdf?fbclid=IwAR 0kVR6 7XORug4ZTtOrLwUdDqpvSBIWdN7AyMRcgIhHqtEpK-yf Zbl92w

12. T. Amon, New Trends on Energy Generation Using Biomass, Simpósio Internacional sobre Gerenciamento de Resíduos Agropecuários e Agroindustriais - II SIGERA, Volume 1, Pages 65-68 (2011)

13. Autoritatea Naţională de Reglementare în domeniul Energiei

14. F-P. Langue, Biomass market trends and bioenergy sector views on EU policy, AEBIOM, (2015)

15. M. Balat, N. Acici and G. Ersoy, Trends in the Use of Biomass as an Energy Source, Journal Energy Sources, Volume 1 Issue 4, Pages 367-378, (2006) 